HORTICULTURE

\title{
Haldina cordifolia (Roxb.) Ridsdale - A Promising Tree for Domestication
}

\author{
S. Muthupandiyan, K. Gireesan and Kannan C.S. Warrier"
}

Institute of Forest Genetics and Tree Breeding, Forest Campus, PB 1061, R.S. Puram Post, Coimbatore, Tamil Nadu, India

*Corresponding author: kannanwarrier@gmail.com (ORCID ID: 0000-0002-5793-6139)

Paper No. 787

Received: $12-04-2019$

Revised: $17-07-2019$

Accepted: 27-08-2019

\begin{abstract}
Haldina cordifolia is a multipurpose tree species spread over moist deciduous forests in India. It possesses high timber quality suitable for flooring, paneling, railway carriages and construction works. It is also being used for medicinal purposes like curing of ulcer, malaria and abdominal disorders since ancient era. Though many phyto-chemicals and pharmacological compounds have been identified from this tree species, the species has not been domesticated so far. A detailed review on the status of this species is presented in this paper.
\end{abstract}

\section{Highlights}

(0 Moist deciduous forest tree suitable for structural work needs domestication.

Keywords: Haldina cordifolia, Multi-Purpose Tree, Domestication

\section{Taxonomy and nomenclature}

Haldina cordifolia (Roxb.) Ridsdale (Synonym: Adina cordifolia Benth. \& Hook. f.) commonly known as Haldu belongs to the family Rubiaceae has a chromosome number of 22 (Bedi et al. 1981). The vernacular names are Manjakadambu (Malayalam), Lampatia, Tarak Chapa (Assamese), Keli- Kadam (Bengali), Heddi (Marathi), Haladwan, Holdarvo (Gujarati), Girikadamba (Sanskrit), Avanu, Kadambe (Kannada), Manjakadambai, Poonteak (Tamil) and Bandaru, Pasupu Kadamba (Telugu). It is also known by the common name "Yellow Teak" due to the colour of the wood.

\section{Distribution and environmental conditions}

It is a South East Asian species. It is distributed throughout India, Burma, Srilanka, Bangladesh, Nepal, Thailand, South China, Bhutan, Vietnam, Myanmar and Malaysia. It is found scattered in deciduous forests throughout the greater part of India, (except in arid regions of Rajasthan) ascending to an altitude of $900 \mathrm{~m}$ in the sub-
Himalayan tract. It is also common in the forests of South India (Iqbal et al. 2009). It grows well under 300-1000m altitude and prefers well-drained soil. Suitable soil $\mathrm{pH}$ range is between 5.5 to 6.5. The annual temperature requirement is within the range of $25^{\circ} \mathrm{C}-35^{\circ} \mathrm{C}$ and prefers a mean annual rainfall between $1000-2000 \mathrm{~mm}$. (Tntreepedia, 2018). It is not frost tolerant. The tree grows in various geological formations such as granite, gneiss, schist, quartzite, trap and laterite up to an elevation of $1000 \mathrm{MSL}$ (Kundu, 2018)

\section{Botanical description}

Haldina cordifolia is a large deciduous tree up to $40 \mathrm{~m}$ tall and $2.2 \mathrm{~m}$ in diameter. The length of clear straight bole may be up to $20 \mathrm{~m}$. Bark pale brown, shallowly pitted, horizontally wrinkled and cracked. Leaves opposite which are broadly oval in shape with heart shaped base and pointed tip. Lamina orbicular, 12$24 \times 12-24 \mathrm{~cm}$, petiole $2.5-5 \mathrm{~cm}$; pubescent beneath, base cordate, apex shortly acuminate; 5-7 nerved from the base; lateral nerves $4-5$ pairs, prominent 
on lower side (Kulkarni et al. 2015). Flowers are bisexual yellow in color in round heads, seeds many with tail at one end and bifid wings on other end. Generally flowering occurs during June -July and fruits will ripen during December-March (Talbot, 1976). The pollen grains are usually tricolpate, oblate, sub-spheroidal but changes from spheroidal to prolate in dried specimens. Most of the pollen grains are rather thin and the size of pollen is $45 \times 42$ $\mu \mathrm{m}$. Pollen production per anther is $8,000-9,000$ and pollen per flowers is $40,000-45,000$. The number of ovules per flower is two and the pollen ovule ratio is $21,000: 1$ (Sikarwar 2005). The seeds are very small and light 0.06 to 0.12 in. long brown with numerous minute longitudinal wrinkles, one end tapering to a point, and the other terminating in apair of pointed appendages. One gram of seeds contains as many as 11000 seeds (Troup 1921).

\section{Reproductive biology and breeding system}

Natural regeneration of the species is sparse. The minute seeds shed during the hot season are often carried to a distance by the wind; in some cases the fruit-heads fall before all the seeds are shed and the seed may germinate with the fruit-heads. The seeds are produced in vast numbers, but the proportion of seedlings which survive and establish themselves is relatively very small. For vegetative propagation, softwood cuttings are the most suitable when compared to hardwood and semi-hardwood cuttings (Kaushal et al. 2010). Cuttings treated with IBA (Indole-3 Butyric Acid) at a concentration of $2000 \mathrm{mgl}^{-1}$ root well (Yadav et al. 2018). Germination takes place within 20-40 days. Apical buds or shoot tips are the ideal explants for in vitro propagation. MS medium supplemented with BAP 1.0\% + NAA $0.5 \%$ was found to be very effective for its micro propagation (Sultana et al. 2015).

\section{Seed collection and processing}

Seeds are shed between April and June; Maturity indices of seeds could be identified through colour and moisture content of the fruit. The color will change from light green to light brown and moisture content of the fruit between $38-46 \%$ at maturity (Jeena et al. 2012). At the time of seed collection, spreading the tarpaulin under the trees and collect the fruits by lopping the branches or plucking. The collected seed should be sun dried for 7 to 10 days and reduce the moisture content between 5-6\% for attaining the maximum germination (Kundu 2018).

\section{Nursery establishment}

Haldina cordifolia does not require any pre treatment for germination. Fresh and dried seeds may be used for germination. As the seeds are minute, instead of nursery beds, germination trays of the size $50 \mathrm{~cm} \times$ $50 \mathrm{~cm}$ can be used for sowing the seeds. Use either soil- vermiculite mixture ( 3 soil: 1 vermiculite) or wet polyurethane sheets as the medium to sow the seeds. About 18000 seeds which weigh around $10 \mathrm{~g}$ can be sown in one tray. Almost 60 per cent of the sown seeds germinate in soil- vermiculite medium and on foam sheets; Raised nursery beds can also be used for germination, with the seed mixed with sand in 1: 3 ratio before sowing. Prick the seedlings in the tray and poly- pot in containers of $23 \mathrm{~cm} \times$ $17 \mathrm{~cm}$ size, filled with potting mixture ( 3 soil : 1 sand). Potted seedlings can be kept in the shaded nursery for 2-3 months with watering once in a day and subsequently in the open for 15-30 days before planting. Data on optimum shade, watering and manure requirements in the nursery are not available (Nair et al. 2004). Growth in the first year is very slow, and the seedlings often reach only 2.5 $\mathrm{cm}$ in height during this time; in the second year growth is faster, and the seedlings develop thick taproots.

\section{Plantation establishment and growth}

Field plant the poly- potted seedlings maintained in the nursery for 5-6 months. Remove the polythene cover without damaging the root system of the seedlings and planted in a suitable pit size of $30 \mathrm{~cm}$ $\times 30 \mathrm{~cm} \times 30 \mathrm{~cm}$ seedlings are to be planted in a such a way that the level of soil around the seedlings provide little terracing to avoid stagnation of water. About 70 per cent of the field- planted seedlings will survive during the first three months. Protection from drought is very essential for the survival of field planted seedlings. Seedlings will grow to a height of $16.7 \mathrm{~cm}$ within a period of eight months in the field (Nair et al. 2004). Data on nutrient deficiencies and their symptoms are not available.

\section{Important insect pest and diseases}

The insect Parotis vertumnalis causes over 50 per cent damage to foliage by folding the leaves and feeding 
from within. Epiplema quadricaudata caterpillars causing defoliation on young trees (Nair et al. 1991) which can be controlled by application of 0.1\% solution of Ekalux 25EC (Quinalphos). Dirades adjutaria also causes defoliation in the month of July to August. Aristobia approximator insect feeds on the bark of the living shoots. The larvae of Dihamnus cervinus bores in the stems of living saplings (Kundu 2018).

Regarding the diseases, Phytophthora spp. causes crown rot when the trees are planted too deep in the soil. Powdery mildew is caused by Podosphaera leucotricha and fire blight also occurs in several areas which is controlled by application of Antibiotic sprays (Streptomycin or Terramycin) during the bloom period (Tntreepedia 2018). Leaf spot and damping off disease occurs at the nursery level.

\section{Wood properties}

The yellowish wood is found to be uniformly fine texture and straight grained. Basic Density range between $503.0 \mathrm{~kg} / \mathrm{m}^{3}$ to $663.5 \mathrm{~kg} / \mathrm{m}^{3}$. Average density at breast height level was $596.7 \mathrm{~kg} / \mathrm{m}^{3}$ (Nair et al. 1991). Sapwood is pale yellowish or yellowish white. Heart wood is deep yellow turning reddish or brownish on exposure. Parenchyma is sparse and indistinct to the naked eye. Rays are fine, numerous and closely spaced. Vessels are small, solitary and in radial multiples of two to three (Anoop and Pasha 2005). Various other wood properties worked out were: Specific gravity: 0.70 at $12 \%$ moisture content. Co-efficient of volumetric shrinkage: $0.45 \%$, total tangential shrinkage (TS): $6.8 \%$, total radial shrinkage (RS): $3.4 \%$, TS/RS ratio is : 2.0 , crushing strength : $55 \mathrm{MPa}\left(1 \mathrm{MPa}=1 \mathrm{~N} / \mathrm{mm}^{2}\right)$, static bending strength : $90 \mathrm{MPa}$, modulus of elasticity : $12770 \mathrm{MPa}$ (Anon, 2012). Air dry weight is $40-42 \mathrm{lb}$ per cubic ft (CSIR, 1948).

\section{Utilization}

Haldina is largely used for structural work. It is one of the best Indian timbers suitable for flooring, paneling and for railway carriages (CSIR, 1948). It is also suitable for pulp and paper, construction, window frames, furniture, bobbins, piano keys and rulers (Chandel et al. 2018). Wood is also used for pencil manufacturing (Trotter 1959). Other uses are canoes and dugouts, planking of river boats, packing cases, cigar boxes, grain- measures, sieve frames, snuff boxes, furniture, yokes combs toys gunstocks, carving and turnery work, brush- backs and drums.

\section{Medicinal uses}

Its leaves, seeds, bark, and roots are used in traditional Indian medicine. Leaves and bark are used for cholera, cold cough, fever, headache, scars and skin blemishes and urinary complaints. Paste of stem bark and leaves are used for curing deep wounds, jaundice, stomachache and swelling in stomach (Jain et al. 2005). Stem bark is used for the treatment of malarial fever, abdominal disorders, inflammation, wound and ulcer (Narayan and Singh 2017). It act as a good antibacterial, antiseptic, anti bilious, anti diabetic and febrifuge agent (Rokade and Pawar 2013).

\section{Other relevant information}

Haldina leaves and young twigs are used as fodder for livestock (Mehta et al. 2013). Methanol extract from the leaves have been proved to possess good antibacterial activities against various pathogens like Staphylococcus aureus, Pseudomonas aeruginosa, Escherichia coli, Streptococcus pneumoniae, Clostridium difficile, Klebsiella pneumonia, Mycobacterium tuberculosis and Bacillus subtillis (Dash et al. 2014).

Isoscopoletin and Umbelliferone, compounds could be isolated from bark and wood of Haldina cordifolia which act as a good bio herbicide against the giant mimosa (Mimosa pigra) weed (Suksungworn et al. 2017).

Nair et al. 1991 recorded 24 characters of leaf variation from 22 different location samples in Kerala.

Tamil Nadu forest department has established an introduction trial of Haldina cordifolia at Arimalam research center, Pudukkotai during 2014 - 2015.

Institute of Forest Genetics and Tree Breeding (Indian Council of Forest Research and Education) Coimbatore in collaboration with Tropical Forest Research Institute, Jabalpur has initiated a five year project from September 2018 on 'Selection and Evaluation of Haldina cordifolia (Roxb.) Ridsdale for Higher Wood Productivity'. 


\section{REFERENCES}

Anon, 2012. Haldu. Disponible en https://tropix.cirad.fr/ FichiersComplementaires/EN/Asia/HALDU.pdf

Anoop, E.V. and Pasha, M.K.S. 2005. Timber identification manual- manual of timbers used by wood based handicrafts industry of Kerala, Uttar Pradesh and Rajasthan, pp. 30-31.

Bedi, Y.S., Bir, S.S. and Gill, B.S. 1981. Cytopalynology of woody taxa of family Rubiaceae from North and Central India. Proceedings of Indian National Science Academy, pp. 708-715.

Chandel, P.K., Prajapati, R.K. and Dhurwe, R.K. 2018. Documentation of NTFP's and medicinal plants available in Dhamtari forest area. Journal of Pharmacognosy and Phytochemistry, 7(1): 1524-1530.

CSIR, 1948. The Wealth of India, Raw Materials, Volume-I, A Dictionary of Indian Raw Materials \& Industrial Product. Council of Scientific \& Industrial Research, Delhi, pp. 32.

Dash, P.P., Chaturvedi, A.K., Mishra, A. and Chaturvedi, D. 2014. Antibacterial activity of methanolic extract of Haldina cordifolia. International Journal of Natural Products Research, 4(4): 95-99.

Iqbal, P.F., Bhat, A.R. and Azam, A. 2009. Antiamoebic coumarins from the root bark of Adina cordifolia and their new thiosemicarbazone derivatives. European Journal of Medicinal Chemistry, 44 (5): 2252-2259.

Jain, A., Katewa, S.S., Galav, P.K. and Sharma, P. 2005. Medicinal plant diversity of Sitamata wildlife sanctuary, Rajasthan, India. Journal of Ethnopharmacology, 102: 143-157.

Jeena, L.S., Kaushal, R., Dhakate, P. M. and Tewari, S.K. 2012. Seed maturation indices for better regeneration and multiplication of Haldu (Adina cordifolia). Indian Journal of Agricultural Sciences, 82 (4): 381-383.

Kaushal, R., Jeena, L.S., Chaturvedi, S., Tewari, L. and Tewari, S.K. 2010. Vegetative Propagation of Adina cordifolia (Roxb.) Hook. F. Ex Brandis. Indian Forester, 136(12): 1693-1698.

Kulkarni, S.S., Hegde, G.R. and Bhat, P. 2015. A field key to the deciduous trees of Anshi national park. Indian Forester, 141(3): 298-307.

Kundu, M. 2018. Haldina cordifolia (Roxb.) Ridsdale. Disponible en https://ign.ku.dk/english/employees/ forest-nature-biomass/?pure $=\mathrm{en} \% 2 \mathrm{Fpublications} \% 2 \mathrm{Fhal}$ dina-cordifolia-roxb-ridsdale(ba46f7b9-1eac-4d3a-aa3ed18ac222d4c0).html
Mehta, H., Dar, M.A., Singh, C. and Chaturvedi, O.P. 2013. Status, potential \& strategies for tree fodder improvement. Central Soil \& Water Conservation Research Institute, Uttarakhand, pp. 251-256.

Nair, K.K.N., Chacko, K.C., Menon, A.R.R., Bhat, K.V., Mathew, G., Ali, M.I.M. and Pandalai, R.C. 1991. Studies on selected indigenous species for future plantation programmes in Kerala, KFRI Research Report, pp. 83-102.

Nair, K.K.N., Mohanan, C. and Mathew, G. 2004. Plantation Technology of Haldina cordifolia (Manja-kadambu). Kerala Forest Research Institute pp.1-7.

Narayan, D. and Singh, P.K. 2017. Ethno botanical importance and herbal medicine in Vindhya region of Eastern Uttar Pradesh, India. Journal of Medicinal Plants Research, 11(25): 403-413.

Rokade, Y. and Pawar, S.P. 2013. A comprehensive review on Adina cordifolia. International Journal of Pharmaceutical Sciences Review and Research, 18(2): 13-16.

Sikarwar, R.S. 2005. Description of pollen morphological studies of Adina Cordifolia Linn. (Rubiaceae). Biosci. Biotech. Res. Asia, 3(1) :153-154.

Suksungworn, R., Srisombat, N., Bapia, S., Upom, M.S., Sanevas, N, Wongkantrakorn, N., Kermanee, P., Vajrodaya, S. and Duangsrisai, S. 2017. Coumarins from Haldina cordifolia lead to programmed cell death in giant mimosa: potential bio-herbicides. Pak. J. Bot., 49(3): 1173-1183.

Sultana, N., Tareq , S.A.M. and Das, S. 2015. In-vitro propagation of Haldu (Adina cordifolia Roxb.). Indian Forester, 141(6): 638-641.

Talbot, W.A. 1976. Forest flora of the Bombay presidency \& Sind. Volume II. Periodical experts, Delhi, pp. 85-86.

Tamil Nadu Tree Pedia. 2018. Disponible en https:// www.tntreepedia.com/treedetails/?id=fcab36e 04f0d1596be2bc84fd6d5db24.

Trotter, H. 1959. The Common Commercial Timbers of India and their Uses. Government of India Press, Delhi, pp. 40.

Troup, R.S. 1921. The Silviculture of Indian Trees. Volume II. International Book Distributors, Dehra Dun, pp. 616-621.

Yadav, D., Kumar, D. and Singh, H. 2018. Vegetative propagation of Adina cordifolia through branch cuttings. International Journal of Current Microbiology and Applied Sciences, 7(1): 2678-2687. 